\title{
How to MEASURE THE TAX BuRden ON LABOUR AT THE MACRO-LEVEL?
}

\author{
JAKOB DE HAAN \\ JAN-EGBERT STURM \\ BJØRN VOLKERINK
}
CESIFO WORKING PAPER NO. 963
CATEgORY 1: PUBlic FinANCE
JUNE 2003

Presented AT CESifo CONFERENCE ON MEASURING THE TAX BURDEN ON LABOUR AND

CAPITAL, Venice, July, 2002

\footnotetext{
An electronic version of the paper may be downloaded

- from the SSRN website:

www.SSRN.com

- from the CESifo website: www.CESifo.de
} 


\title{
How to MEASURE THE TAX BURDEN ON LABOUR AT THE MACRO-LEVEL?
}

\begin{abstract}
The purpose of this paper is threefold. First, we survey the way in which the tax burden on labour has been proxied for in recent multi-country macro-economic studies. Second, we critically evaluate these proxies. Finally, we examine to what extent the conclusions of some studies change if some alternative indicator for the tax burden on labour is employed. We conclude that the widely used tax ratios as developed by Mendoza et al. (1994) may not be very reliable. The choice of the indicator for the tax burden on labour is also shown to affect the conclusions of some well-known empirical models.
\end{abstract}

JEL Code: H20, H29.

Keywords: tax ratios, labour, average effective tax rates, unemployment.

\author{
Jakob deHaan \\ Faculty of Economics \\ University of Groningen \\ PO Box 8009700 \\ AV Groningen \\ The Netherlands \\ j.de.haan@eco.rug.nl
}

\author{
Jan-Egbert Sturm \\ CESifo (University of Munich \& Ifo Institute) \\ Poschingerstrasse 5 \\ 81679 Munich \\ Germany \\ Sturm@cesifo.de
}

\author{
Bjørn Volkerink \\ Maastricht University \\ P.O. Box 616 \\ 6200 MD Maastricht \\ The Netherlands
}

We would like to thank the participants in the CESifo Venice Summer Institute 2002 workshop, especially Steven Clark, two referees and Peter Birch Sørensen for their very helpful comments on a previous version of the paper. 


\section{Introduction}

Various recent studies have investigated the impact of the labour tax burden on unemployment, using some kind of macro-econometric model. Generally, it is found that this impact depends on the institutional features of the labour market. ${ }^{1}$ For instance, Elmeskov, Martin and Scarpetta (1998) conclude that different collective bargaining arrangements influence the way in which the tax wedge affects unemployment. The strongest impact is found for countries with intermediate levels of centralisation/co-ordination in the labour market. ${ }^{2}$ Likewise, Daveri and Tabellini (2000) argue that the increase in unemployment and the slowdown in economic growth in continental and nonNordic Europe stem from higher labour taxes in combination with the institutional characteristics of the labour market. An exogenous and lasting increase in labour costs reduces labour demand. Due to a substitution of capital for labour, the marginal product of capital falls, according to these authors, diminishing the incentive to invest and thus to grow.

Daveri and Tabellini (2000) have used the so-called tax ratios of Mendoza, Milesi-Ferretti and Asea (1997) as approximations for effective tax rates. To calculate tax ratios, tax revenues are expressed as a ratio of some aggregate tax base (e.g. labour income, capital income, consumption). In other papers - like the study by Elmeskov, Martin and Scarpetta (1998) - the tax burden on labour is proxied by the tax wedge, i.e. the difference between gross labour costs to employers and the consumption wage paid to employees (Scarpetta, 1996).

The purpose of this paper is threefold. First, we will survey the way in which the tax burden on labour has been proxied for in recent macro-economic studies that relate to a number of OECD countries. So, we focus on studies at the macro-level and do not take micro-econometric evidence into account. ${ }^{3}$ We also do not deal with country specific studies. ${ }^{4}$

Second, we will compare the various proxies used. We find that even though the various proxies for the tax burden on labour differ substantially, their correlation is generally quite high. It is quite amazing that many authors examining the relationship between the tax burden on labour and unemployment hardly bother to identify the attributes of a tax burden measure that are important in explaining the possible impact of labour taxes on unemployment. For instance, is a marginal or an average tax rate needed, and should income-tested benefits be included or not?

Finally, we will examine to what extent the conclusions of some widely cited studies change if some alternative indicator for the tax burden on labour is employed. To be more specific, we reestimate the unemployment models of Daveri and Tabellini (2000) and Nickell (1997) and the investment model of Mendoza et al. (1997). In general, we conclude that the significance of the impact of the tax burden on unemployment is not very sensitive with respect to the choice of the indicator, which is in line with the reported high correlation of most indicators.

The remainder of the paper is organised as follows. Section 2 summarises studies that we are aware of and discusses the tax wedge, while section 3 discusses labour tax ratios. The tax wedge and the labour tax ratio are widely used in the empirical literature as proxies for the tax burden on labour. Section 4 presents our empirical results and the final section offers some concluding comments.

\section{Tax burden on labour: tax wedge}

Table 2 summarises recent macro-economic multi-country studies examining the effect of taxes on labour. ${ }^{5}$ Basically two (not mutually exclusive) approaches can be discerned. In one group of 
studies indicators for the tax-wedge are used, while in another group of studies tax ratios (sometimes also called effective or implicit tax rates) are used as proxies for the tax burden on labour. Even though they are quite different in many respects, both proxies are average tax rates. ${ }^{6}$ 


\begin{tabular}{|c|c|c|c|c|c|c|c|}
\hline 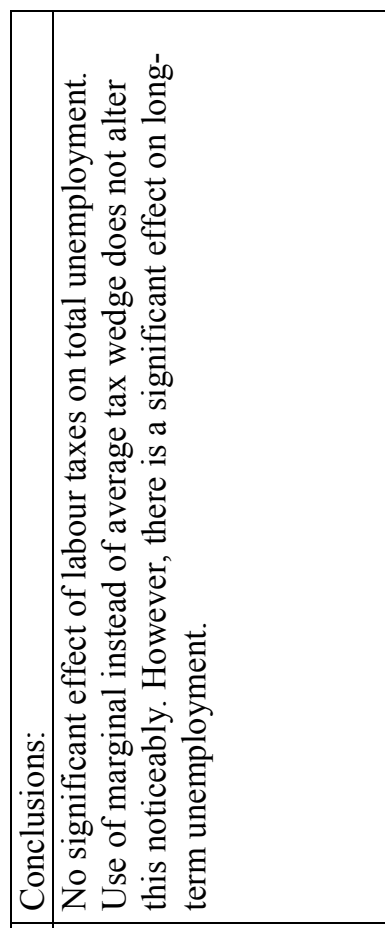 & 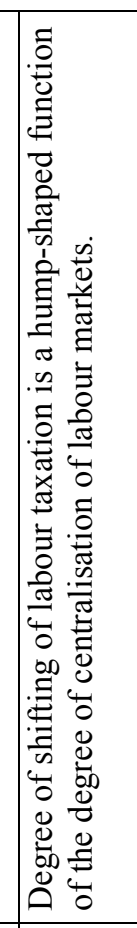 & 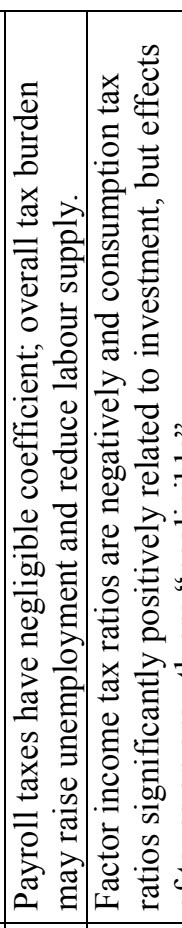 & 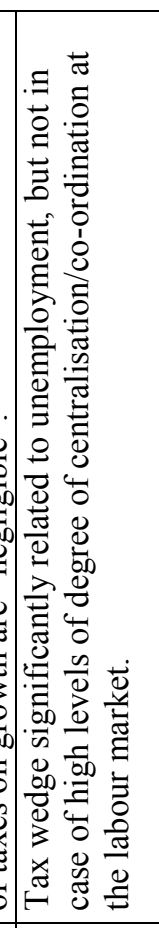 & 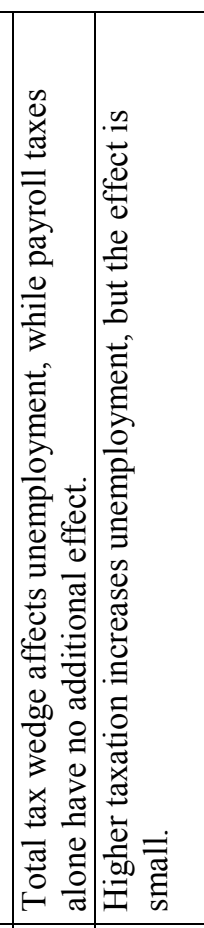 & 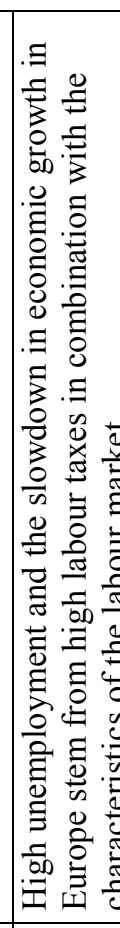 & 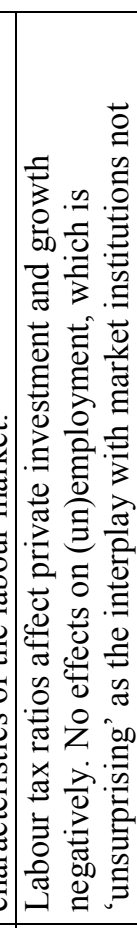 & 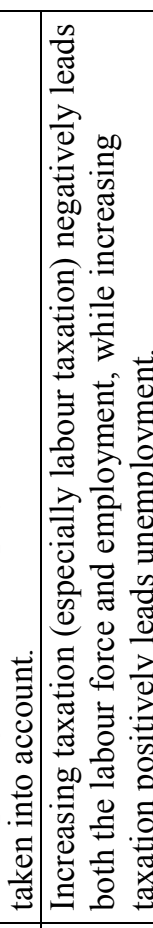 \\
\hline 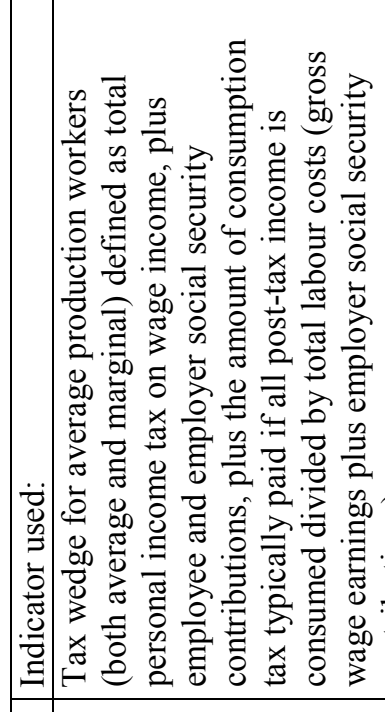 & 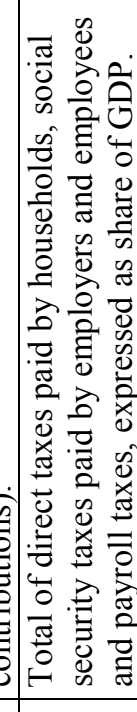 & 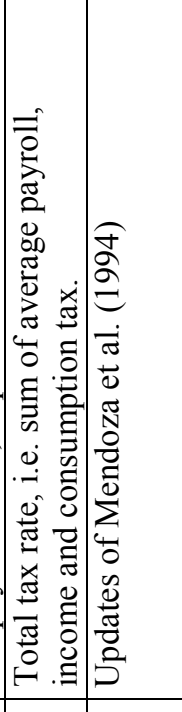 & 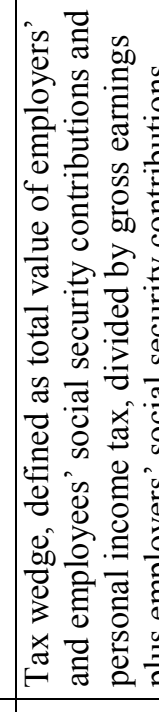 & 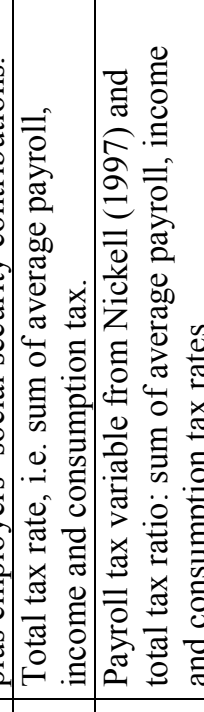 & 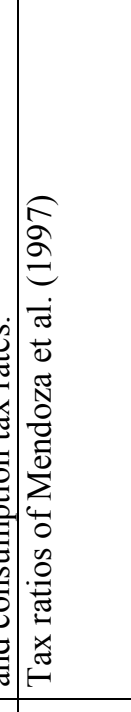 & 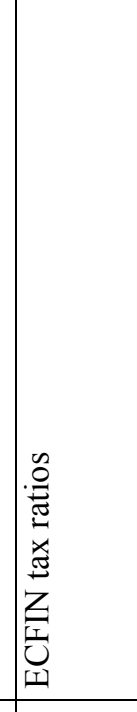 & 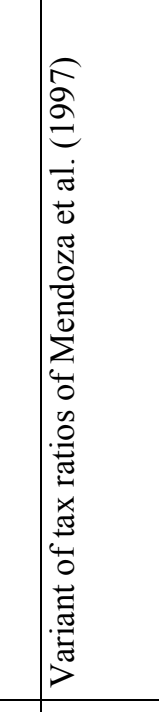 \\
\hline 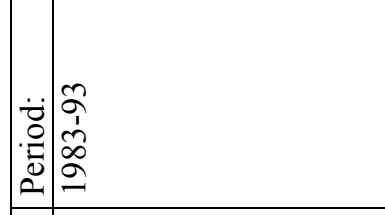 & 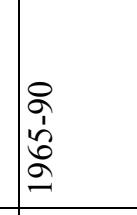 & 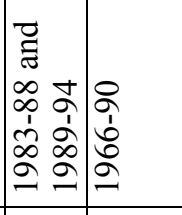 & 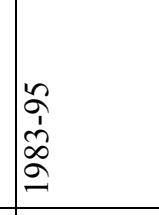 & 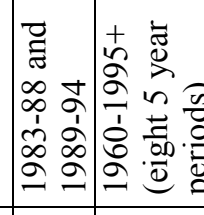 & & 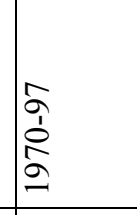 & 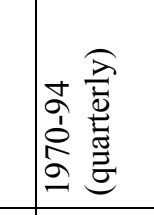 \\
\hline 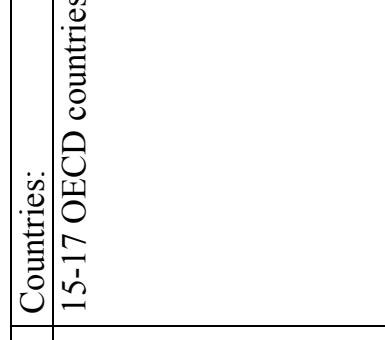 & 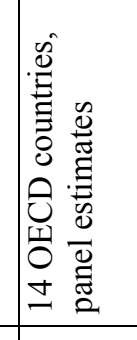 & 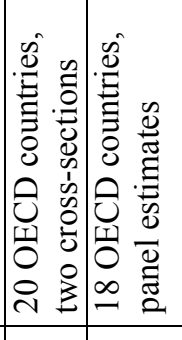 & 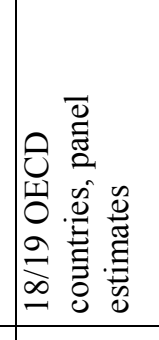 & 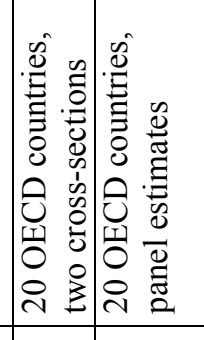 & 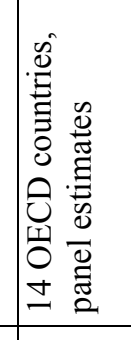 & 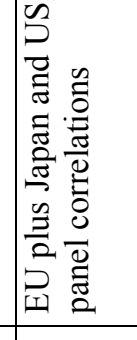 & 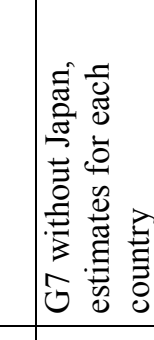 \\
\hline 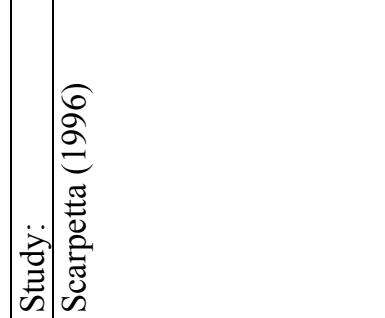 & 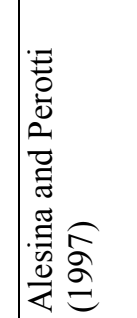 & 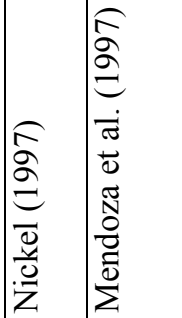 & 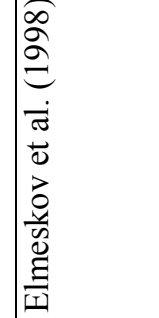 & 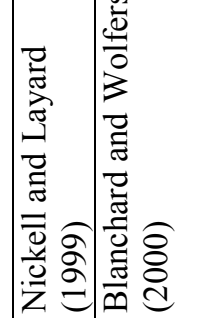 & 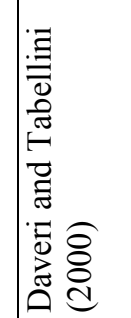 & 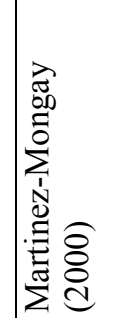 & 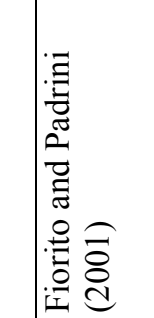 \\
\hline
\end{tabular}




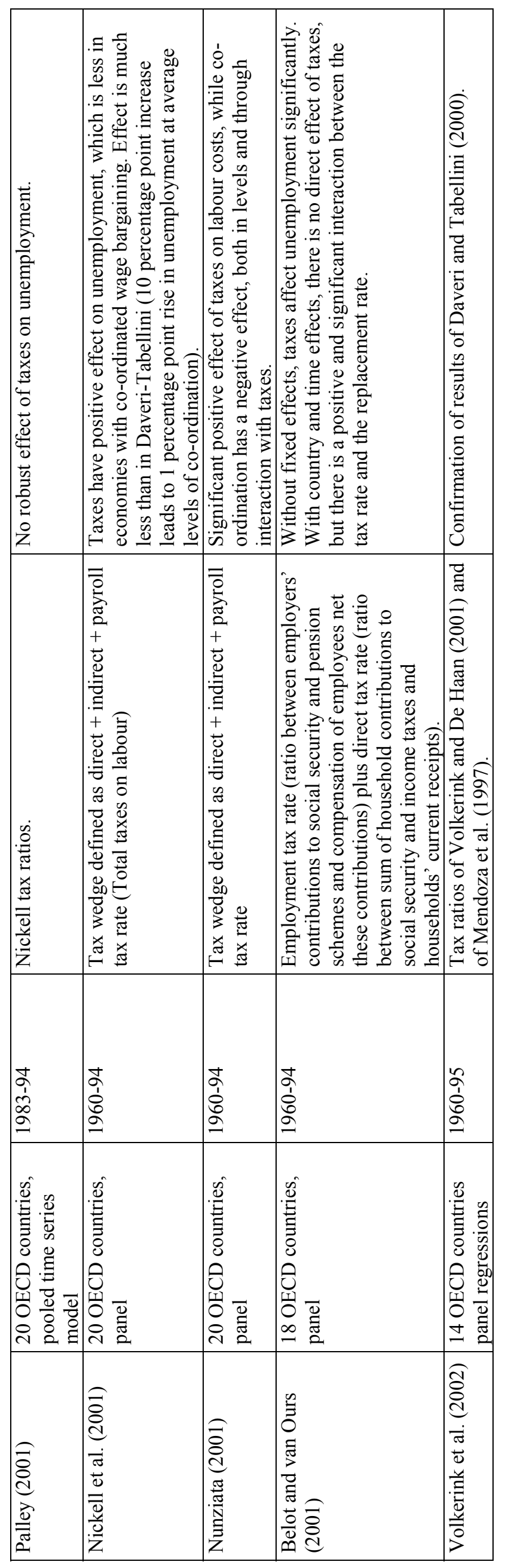


Taxes drive a wedge between the price of labour to employers and the return of labour for the employees. Therefore, taxation influences decisions of employees about labour force participation and labour supply. Similarly, taxation of labour affects the wage offered by employers. Simple economic theory does not always provide a clear answer as to how agents will react to taxes (OECD, 1995). For instance, an increase in tax rates on labour income may induce workers to work more in order to compensate for the loss of consumption possibilities. Alternatively, they may decide to work less as leisure has become more attractive due to the higher tax rate. Likewise, higher taxes on labour will raise the cost of employing someone and will therefore reduce employment to the extent that wages do not fall correspondingly. Under competitive markets, wages will fall by the amount of the tax increase provided that labour is inelastically supplied. However, labour (and product) markets may not be competitive. Unions and employers may take tax changes into account when bargaining for wages. Trade unions may, for instance, try to shift the higher burden of taxation to employers. So it depends on the bargaining structure at the labour market and the bargaining power of the parties involved how taxes will affect the labour market. ${ }^{7}$

Unfortunately, most of the papers summarized in table 2 do not provide some explicit theoretical reasoning that leads to a clear identification of the tax burden measure one would want to consider. Most studies summarized in table 2 examine the impact of the average effective tax rate on an 'average' or 'typical' worker. Thereby, they are implicitly referring to the theory of imperfect labour markets which implies that, in an imperfect labour market, a higher average tax rate on labour income generates a tax push effect on real wages, which is likely to create additional unemployment.

To illustrate this, we sketch the bargaining model of Scarpetta (1996) in which imperfectly competitive profit-maximising firms face exogenously determined product market conditions and predetermined capital and technology (Layard, Nickell and Jackman, 1991). Ignoring labour growth and productivity effects, the model can be summarised by three equations, which describe (the logarithm of) labour demand $\left(L_{d}\right)$, the wage-setting schedule, and (the logarithm of) labour supply $\left(L_{s}\right)$.

$L_{d}=-\alpha(w-p)-\beta Z_{n}-w^{u}$,

where $w$ and $p$ are the logarithms of gross wages (including taxes) and prices, respectively. $Z_{n}$ is a vector of variables influencing labour demand and $w^{u}$ is unanticipated wages, which account for expectational errors. Real wages are assumed to be decreasing in actual unemployment $(u)$ and increasing in wage push factors $\left(Z_{w}\right)$, including features of the wage bargaining process and the average tax rate:

$w-p=\delta_{1} Z_{w}-\gamma_{1} u-p^{u}$,

where $p^{u}$ denotes unexpected price changes. Labour supply depends on factors affecting participation decisions $\left(Z_{p}\right)$ :

$L_{s}=\delta_{2} Z_{p}$

Taxes are also included in $Z_{p}$. The marginal tax rate seems to be the relevant rate for addressing the issue of whether or not to increase hours worked, while the average tax rate would seem to be the relevant rate for the labour market participation decision. Equilibrium unemployment $\left(u^{*}\right)$ is:

$$
u^{*}=\frac{\alpha \delta_{1} Z_{w}}{1+\alpha \gamma_{1}}+\frac{\delta_{2} Z_{p}+\beta Z_{n}}{1+\alpha \gamma_{1}}
$$


So, the equilibrium unemployment rate is determined by various factors, including the average tax rate. Still, the analysis also suggests that the marginal tax rate may be relevant. ${ }^{8}$ If the marginal and average tax rates are highly correlated, regressions that only include the average tax rate may lead to a biased estimate of the effect of the average tax rate. Scarpetta (1996) is the only study summarised in table 2 , which also takes marginal tax rates into account.

The analysis also suggests that if one is interested in the possible tax-push effect of the average labour tax on unemployment, it is important that the tax rate used isolates taxes on labour and does not include taxes on transfers. A tax that falls evenly on wages and benefits may not generate a tax push effect on wage claims, since it does not increase the net replacement ratio. So in evaluating the usefulness of alternative tax ratios for the purpose of estimating the effects on unemployment it thus becomes important to consider the extent to which measures are 'contaminated' by taxes on transfers. ${ }^{9}$

Even if it is clear from this simple model that some (properly defined) average tax rate can be used in a macro-econometric model explaining unemployment, the model does not provide much guidance on some other important attributes of the tax burden measure. For instance, should other than labour income taxes be included in the tax wedge? In principle, just about every tax can have an effect on the labour market. Still, most studies are confined to taxes on labour, although there are differences as to how the tax wedge is measured. The most important difference is whether consumption taxes should be included in the calculation of the tax wedge. Nickell (1997) argues that total taxes, i.e. payroll, income and consumption taxes, are the tax burden on labour. The total tax rate is a crude measure of the tax wedge between labour costs and take-home pay. ${ }^{10}$ Switching between these taxes will not have an important effect. Nickell (1997, p. 69) argues:

"Employees are interested in what their wages can buy. So if their income taxes are cut by 10 percent and the cost of consumption is raised by 10 percent, post-tax real wages are unchanged and so is labour market behaviour. So, broadly speaking, what really counts is the sum of payroll taxes, income taxes and consumption taxes; the total tax burden on labour."

One strategy to estimate the tax wedge is to combine the analysis of statutory tax schedules with data on income distribution of the household and business sectors. McKee, Visser and Saunders (1986) have calculated the (average and marginal) tax wedge on annual labour income data in 19 OECD countries using the 'average production worker (APW)' income level and information on individual income tax and social security schedules. The basic approach is straightforward: a small number of 'typical' families are chosen and the tax rules for each country are applied to them in order to calculate average and marginal effective tax rates. Nowadays, the OECD publishes data for eight types of tax payers in Taxing Wages (see Heady (2002) for further details). McKee et al. define the tax wedge as the difference between gross labour costs to employers and the consumption available to employees from increasing labour input by an additional unit. The tax rate is the ratio of the tax wedge to gross labour costs. However, the tax burden for the 'average production worker' may not be representative for the tax burden on all workers. ${ }^{11}$ Furthermore, estimates from statutory tax rates are complicated because each country has a range of exemptions and allowances that change over time and are difficult to aggregate in each period and even more so in a time-series setting (Fiorito and Padrini, 2001). So, various empirical studies in which the effects of the tax wedge are examined employ other proxies for the tax wedge.

A good example is the study by Elmeskov, Martin and Scarpetta (1998), who have estimated various reduced-form models for unemployment. They define the tax wedge as the total value of employers' and employees' social security contributions and personal income tax, divided by gross earnings plus employers' social security contributions. These authors conclude that different collective bargaining arrangements influence the way in which the tax wedge affects unemployment. The effect of the tax wedge on unemployment is absent in countries with a highly centralised/co-ordinated wage bargaining system, and only marginally significant in countries with 
a decentralised system, while it is highly significant in countries with intermediate levels of centralisation/co-ordination at the labour market.

These results contrast somewhat with those of Blanchard and Wolfers (2000), who find that their tax variable is significant in their full sample of 20 OECD countries. ${ }^{12}$ In sharp contrast, Palley (2001) finds no effect of taxes on unemployment. These diverging conclusions are quite remarkable because many of the studies summarised in table 2 consist of simple reduced-form models for unemployment of the form (see also Daveri, 2001):

$\mathrm{U}_{\mathrm{i}, \mathrm{t}}=$ constant $_{\mathrm{i}}+\beta \mathrm{TAX}_{\mathrm{i}, \mathrm{t}}+\gamma \mathrm{X}_{\mathrm{i}, \mathrm{t}}+\mathrm{e}_{\mathrm{it}}$,

where $\mathrm{i}$ is the country index, $\mathrm{t}$ is the time index (often referring to period averages), $\mathrm{U}$ is the unemployment rate, TAX is some proxy for the tax burden on labour and $\mathrm{X}$ is a vector of control variables.

As pointed out before, instead of using some indicator for the tax wedge many studies have employed so-called tax ratios to examine the relationship between labour taxes and unemployment. Probably the best-known study in this line of research is by Daveri and Tabellini (2000). They have used the tax ratios constructed by Mendoza, Milesi-Ferretti and Asea (1997) in a panel model like equation (5) for 14 OECD countries over the period 1965-95. These authors conclude that high labour taxes - in combination with the institutional set-up of the labour market - strongly contribute to current high unemployment levels in Europe. ${ }^{13}$ Their results suggest that, over a period of 30 years, the observed rise of about nine percentage points in the labour tax rate corresponds to a rise in unemployment of about four percentage points. These findings are often used to support a reduction in taxes on labour in Europe - preferably in a co-ordinated fashion - to stimulate employment growth. In the following section, we will discuss the construction of tax ratios in more detail.

\section{Tax burden on labour: tax ratios}

It follows from the previous section that quite a number of recent studies have used so-called tax ratios (or effective tax rates), which are based on the methodology inspired by Lucas (1990) and developed by Mendoza, Razin and Tesar (1994) and the subsequent update thereof of Mendoza, Milesi-Ferretti and Asea (1997). Tax ratios aim to give an easy to compute indication of the tax burden on, for example, different sources of income or production factors. On the basis of limited information - a few entries from the OECD's National Accounts statistics and the Revenue Statistics - it is possible to calculate indicators of the tax burden on, for example, labour. ${ }^{14}$

The fundamental methodological problem in constructing labour income tax ratios is that most tax categories as distinguished in the OECD Revenue Statistics relate to more than one macroeconomic category (labour and capital income). Consequently, it is impossible to calculate tax ratios without using some technique to artificially separate out the amounts to be allocated to various macroeconomic categories. This is most evident for the personal income tax. The category taxes on income, profits and capital gains on individuals in the OECD Revenue Statistics includes taxes on labour, taxes on capital, personal taxes on income paid by the self-employed, and - at least in some countries - taxes on transfers. Other revenue categories as distinguished in the OECD Revenue Statistics are plagued by the same problem. Social security contributions (category 2000) are, for example, paid by employees (labour) and - in various countries - also by recipients of social security benefits and by the self-employed, whose income is partly earned by employing capital.

Table 2 shows (employed) labour income tax ratios as calculated in the studies that we are aware of. Our starting point, the study of Mendoza, Razin and Tesar (1994), distinguishes five tax ratios. Two are relevant for this study, the personal income tax ratio $\left(\tau_{\mathrm{per}}\right)$, and the labour income $\operatorname{tax} \operatorname{ratio}\left(\tau_{\mathrm{lab}}\right) .{ }^{15}$ 
Table 2. Labour Income Tax Ratios: An Overview ${ }^{a}$

Mendoza, Razin and Tesar (1994)

$\tau_{\text {per }}$

$\tau_{\text {lab }}$

$\tau_{\text {per }}$

$\tau_{\text {lab }}$

$\tau_{\text {per }}$

$\tau_{\text {lab }}$

$\tau_{\text {per }}$

$\tau_{\text {lab }}$

$\tau_{\text {lab }}$

1000

1100

1110

1120

1200

2000

2100

2200

2300

2400

3000

OS

OSPUE

$\mathrm{W}$

PEI
$1100 /(\mathrm{W}+\mathrm{OSPUE}+\mathrm{PEI})$

$\left(\tau_{\text {per }} \cdot \mathrm{W}+2000+3000\right) / \mathrm{W}+2200$

Directorate General II of the European Commission (1997)

Same method as Mendoza et al. (1994)

Same method as Mendoza et al. (1994)

OECD (2000)

$1100 /(\mathrm{W}-2100+$ OSPUE + PEI $-2300-2400)$

$\left(\tau_{\text {per }} \cdot(\mathrm{W}-2100+\mathrm{WSE})+2100+2200+2300+\alpha \cdot 2400+3000\right) /(\mathrm{CoE}$

+ WSE + 2300)

Where WSE $=\mathrm{ES} \cdot((\mathrm{W}-2100) / \mathrm{EE})$, and

$(\mathrm{W}-2100+\mathrm{WSE} /(\mathrm{OSPUE}+\mathrm{PEI}-2300+\mathrm{W}-2100)=\alpha$

Fiorito and Padrini (2001)

Same method as Mendoza et al. (1994)

$\left(\tau_{\text {per }} \cdot(\mathrm{W}+\mathrm{YSEL})+2000\right) /(\mathrm{W}+2100+2200+\mathrm{YSEL})$

Where YSEL $=(\mathrm{W} / \mathrm{EE}) \cdot \mathrm{ES}$

Volkerink and De Haan (2001) ${ }^{\mathrm{b}}$

$(\lambda \cdot 1100+2100+2200+3000) /(\mathrm{CoE}+3000)$

Taxes on income, profits, and capital gains

Taxes on income, profits, and capital gains on individuals

On income and profits

On capital gains

Taxes on income, profits, and capital gains on corporations

Social security contributions

Social security contributions of employees

Social security contributions of employers

Social security contributions of self- and non-employed

Social security contributions un-allocable between 2100, 2200, and 2300

Taxes on payroll and workforce

Operating surplus of corporate and quasi-corporate enterprises

Operating surplus of private unincorporated enterprises

Wages and salaries

Property and entrepreneurial income 


$\begin{array}{ll}\text { CoE } & \text { Compensation of employees } \\ \text { EE } & \text { Employment (number of dependent employees) } \\ \text { ES } & \text { Number of self-employed }\end{array}$

Notes:

${ }^{a}$ Eurostat (1997) and Martinez-Mongay (2000) are not shown here due to incompatibilities with the methodologies displayed here.

${ }^{\mathrm{b}} \lambda$ is explained in the text.

${ }^{c}$ In contrast to the item Wages and Salaries, the item Compensation of Employees consists of wages and salaries, employers' contributions to social security contributions, and employers' contributions to private pension and social welfare plans.

Source: Adapted and updated from Volkerink and De Haan (2001). 
The personal income tax ratio developed by Mendoza, Razin, and Tesar (1994) is defined as the ratio of revenues from taxes on income, profits, and capital gains of individuals (category 1100 in the OECD Revenue Statistics) to the tax base that consists of wages and salaries (W), the operating surplus of unincorporated enterprises (OSPUE) and the property and entrepreneurial income of households (PEI).

Directorate General II of the European Commission (1997), OECD (2000), MartinezMongay (2000), and Fiorito and Padrini (2001) use the same detour as Mendoza, Razin, and Tesar (1994) of first calculating a personal income tax ratio in order to calculate labour (and capital) income tax ratios. The EC study, and Fiorito and Padrini (2001) use the same methodology as Mendoza, Razin, and Tesar (1994), whereas the OECD study includes category 2400 (social security contributions not allocable to any specific group) in the numerator.

Mendoza, Razin and Tesar (1994) define the labour income tax ratio as the product of the personal income tax ratio $\left(\tau_{\mathrm{per}}\right)$ and wages and salaries $(\mathrm{W})$ plus total social security contributions (2000) and taxes on payroll and workforce (3000) over the sum of wages and salaries (W) plus employers' social security contributions (2200). The calculation of the tax ratio on labour income by Mendoza, Razin and Tesar (1994) was copied by the Directorate General II of the European Commission (1997).

The OECD (2000) study has also used this concept, albeit with different components. As shown in table 2 , the expression for $\tau_{\text {per }}$ is different; the factor is not multiplied by $\mathrm{W}$, but by $\mathrm{W}$ minus employee's social security contributions (W-2100). It is thus assumed that the self-employed 'pay' themselves a salary that equals the average employment wage. This income is proxied by multiplying labour income, excluding social security contributions (W-2100), by the share of the self-employed (SE) to the number of dependent employees (EE). The numerator of the labour income tax ratio furthermore includes both employees' (2100) and employers' (2200) social security contributions as well as part of non-allocable social security contributions $(\alpha \cdot 2400)$. The tax base consists of total compensation of employees plus the 'income' of the self-employed plus social security contributions by the self- and non-employed (CoE+WSE+2300). The 'compensation of employees' equals the sum of wages and salaries, employer's contributions to social security and employers' contributions for private pension and welfare plans.

Carey and Rabesona (2002) have presented a modified OECD (2000) methodology for calculating the labour income tax ratio. The major changes with respect to the original methodology are allowing for the deductibility of social security contributions, enlarging the tax base for the labour income tax ratio by including payroll taxes, and a refinement in the separation of security contributions bearing on labour or capital income. Moreover, the authors test for the sensitivity of the estimates by relaxing several assumptions about, for example, the split of income taxes paid by the self-employed. The modified estimates that result, are, however, highly correlated with the original estimates.

Due to incompatibilities in terms of data, the methodology used by Martinez-Mongay (2000) is not explicitly displayed in table $2 .{ }^{16}$ All in all, his approach is, however, quite comparable to the Mendoza, Razin and Tesar (1994) methodology. The main differences with respect to the personal income tax ratio are the inclusion of (part of) the net operating surplus in the denominator, thus implicitly assuming that profits are fully distributed, and assigning more property income to personal income, supplementary to PEI. The major differences compared to the methodology of Mendoza, Razin and Tesar (1994) are that, self-employed income is decomposed into two components, attributed to labour and capital income, respectively, and the denominator includes the compensation of employees, and not just wages and salaries.

Fiorito and Padrini (2001) use a similar method to separate the income from the selfemployed into a component that can be attributed to labour and capital, respectively. This is done by multiplying the average wage sum (total wages over the number of employed, or W - EE) by the number of the self-employed (SE). The labour income tax ratio is rather similar to the one derived by Mendoza, Razin and Tesar (1994). However, not only the total wage sum, but also the 'imputed 
wage of the self-employed' (YSEL) are multiplied by the personal income tax ratio to estimate the tax burden on labour income. Item 3000 (taxes on payroll and workforce) is not included in the numerator. Obviously, the denominator also includes the imputed labour income of the selfemployed (YSEL).

Eurostat (1997) has also constructed a tax ratio on employed labour. The ratio is defined as the fraction of taxes on employed labour and the compensation of employees - which includes gross wages, wage taxes, and social security contributions of both employees and employers. Eurostat uses its own data, however, so that the exact construction of the tax ratios differs significantly from the Mendoza, Razin and Tesar (1994) approach. National authorities in some cases have indicated the percentage of taxes on income that can be attributed to labour or other income.

What is wrong with labour tax ratios in general? Some studies use the personal income tax ratio as an intermediate step in calculating labour and capital income tax ratios. This is problematic since income from labour, capital income and transfers is included in the 'tax base' of personal income. Furthermore, these studies assume that the same average tax rates apply to all these income categories. This assumption is intuitively implausible, since some income components are largely exempted from taxation, and furthermore, most OECD countries apply different statutory tax rates to different sources of income. The OECD (2000) study goes somewhat in the right direction by refining the personal income tax ratio to control for, for example, the (lower) income tax rates on social security, as shown in Adema, Einerhand, Eklind, Lotz and Pearson (1996) and Adema (1999). This still does not correct for the fundamental problem caused by different tax rates on labour and capital income, however. Eurostat (1997) has opted for a more piecemeal approach. The initial problem remains unsolved, however, since this approach still assumes that average tax rates on both types of income are more or less the same.

Due to lack of data, the problem identified here is hard to overcome. Based on the OECD Revenue Statistics, for only three countries, a (global) split in revenues from income taxes by different sources of income can be made. However, sometimes further information can be used (Directorate General XXI of the European Commission, 1998). In several cases, withholding taxes on certain kinds of income (for example, wage taxes) can be identified which may serve to approximate the parts of the income tax attributable to income from labour, capital, etc. Another possibility is to split the income tax revenues on the basis of data provided by Member States concerned. This is done in the Structures of the Taxation Systems in the EU for some countries. Third, a rough split can be obtained by using National Accounts data on main aggregates (for example, gross salaries divided by gross salaries plus the net operating surplus). However, if this differentiated approach - denoted by $\lambda$ in table 2 - is followed, a uniform method can no longer be applied to all countries under review. This is the approach followed by Volkerink and De Haan (2001).

As far as the income from self-employment is concerned, this income is typically earned by combining labour and capital. As the Directorate General XXI of the European Commission (1998) points out, the capital input can be almost zero (an opera singer) or very high (farmers) and it is difficult, if not impossible, to split income taxes paid by the self-employed into a labour and capital part. Therefore, it seems desirable not to subsume these taxes under labour or capital taxes but to present them as a separate category.

A further difficulty with respect to the labour income tax ratio is the choice of the correct tax base. Mendoza, Razin and Tesar (1994), the Directorate General II of the European Commission (1997) and Fiorito and Padrini (2001) use the items wages and salaries and employers' social security contributions. Eurostat (1997) and Martinez-Mongay (2000) use the item compensation of employees. This includes employers' contributions for private pension and welfare plans. Since the taxes are assigned to total labour costs of employers, the second approach seems preferable. A significant part of the employer contributions may be voluntary, but they undoubtedly are part of total labour costs. This is also in line with National Accounts conventions. Volkerink and De Haan 
(2001) redefined the denominator to include the compensation of employees and all taxes on payroll and workforce. These are the total labour costs of employees to employers. Under this approach, the following items have to be lumped together: gross wages, employers' social security contributions (2200), category 3000 and employers' contributions for private pension and welfare plans. The numerator should then include employers' and employees' social security contributions (2100 and 2200 , excluding social security contributions paid by self- and non-employed), taxes on payroll and workforce (3000), and all income taxes paid on labour income.

All variables discussed so far, aim to proxy for the tax burden on labour. To what extent do they provide similar information? To answer this question, we will first analyse some simple correlation coefficients. Table 3 shows the correlation of the following indicators for the tax burden on labour:

- The indicator of Alesina and Perotti (1997) (AP)

- The tax wedge of Elmeskov et al. (1998) (EMS)

- The tax wedge of Nickell and Layard (1999) (NL)

- The labour tax ratio of Mendoza et al. (1997) (MMA)

- The labour tax ratio of Martinez-Mongay (2000) (M-M)

- The labour tax ratio of OECD (2000) (OECD)

- The labour tax ratio of Volkerink and De Haan (2001) $(\mathrm{VdH}) .{ }^{17}$

Every correlation coefficient has been calculated for the maximum number of observations possible (shown in parentheses). The Nickell-Layard indicator is only available for time-period averages, whereas the other indicators are available on an annual basis. This explains why the correlations on an annual basis (shown in the upper-right part of table 3) could not be calculated for the NL indicator. The correlations between the various indicators using the period averages over 1983-88 and 1989-94 are shown in the lower-left part of table 3. To calculate these correlations, the annual data for the other indicators were first transformed into period averages.

It is very remarkable that the correlations are generally quite high. With the exception of the correlations between the indicators of Alesina and Perotti (1997), Nickell (1997) and the tax ratio of Volkerink and De Haan (2001), all correlation coefficients are higher than 0.75. 
Table 3. Correlation between various indicators for the tax burden on labour

\begin{tabular}{|l|c|c|c|c|c|c|c|}
\hline & AP & EMS & NL & MMA & M-M & OECD & VdH \\
\hline AP & 1 & 0.945 & n.a. & 0.861 & 0.874 & 0.920 & 0.684 \\
\hline EMS & $(638 / 43)$ & $(545)$ & & $(351)$ & $(423)$ & $(291)$ & $(164)$ \\
\hline NL & 0.937 & 1 & n.a. & 0.917 & 0.928 & 0.914 & 0.894 \\
& $(39)$ & $(593 / 41)$ & & $(377)$ & $(391)$ & $(317)$ & $(169)$ \\
\hline MMA & 0.780 & 0.807 & 1 & n.a. & n.a. & n.a. & n.a. \\
& $(37)$ & $(39)$ & $(40)$ & & & & \\
\hline M-M & 0.873 & 0.865 & 0.780 & 1 & 0.904 & 0.928 & 0.918 \\
& $(33)$ & $(31)$ & $(30)$ & $(25)$ & $(459 / 34)$ & $(249)$ & $(164)$ \\
\hline OECD & 0.926 & 0.910 & 0.799 & 0.930 & 0.848 & 1 & 0.804 \\
& $(39)$ & $(41)$ & $(39)$ & $(35)$ & $(31)$ & $(328 / 41)$ & $(134)$ \\
\hline \multirow{2}{*}{ VdH } & 0.644 & 0.854 & 0.524 & 0.888 & 0.826 & 0.810 & 1 \\
& $(17)$ & $(17)$ & $(17)$ & $(15)$ & $(17)$ & $(17)$ & $(169 / 17)$ \\
\hline
\end{tabular}

Note: the calculations in the upper-right part of the table are based on annual observations, while in the lower-left part we have used period averages for 1983-88 and 1989-94. Figures in parentheses show the number of observations.

To analyse this issue in somewhat more detail, figures 1 and 2 show some of the indicators for Austria and Belgium. These countries have been selected on the basis of the availability of detailed information on the distribution of the various components of the personal income tax. In other words, for these countries we are pretty sure that the labour tax ratio as calculated in Volkerink and De Haan (2001) is quite a reliable proxy for the tax burden on labour in comparison to the tax ratios calculated on the basis of the methodology of Mendoza et al. (1994). It follows that the various indicators follow a very similar trend, although the estimates of the level of the tax burden differ substantially. 
Figure 1. Various indicators for the tax burden on labour for Austria.

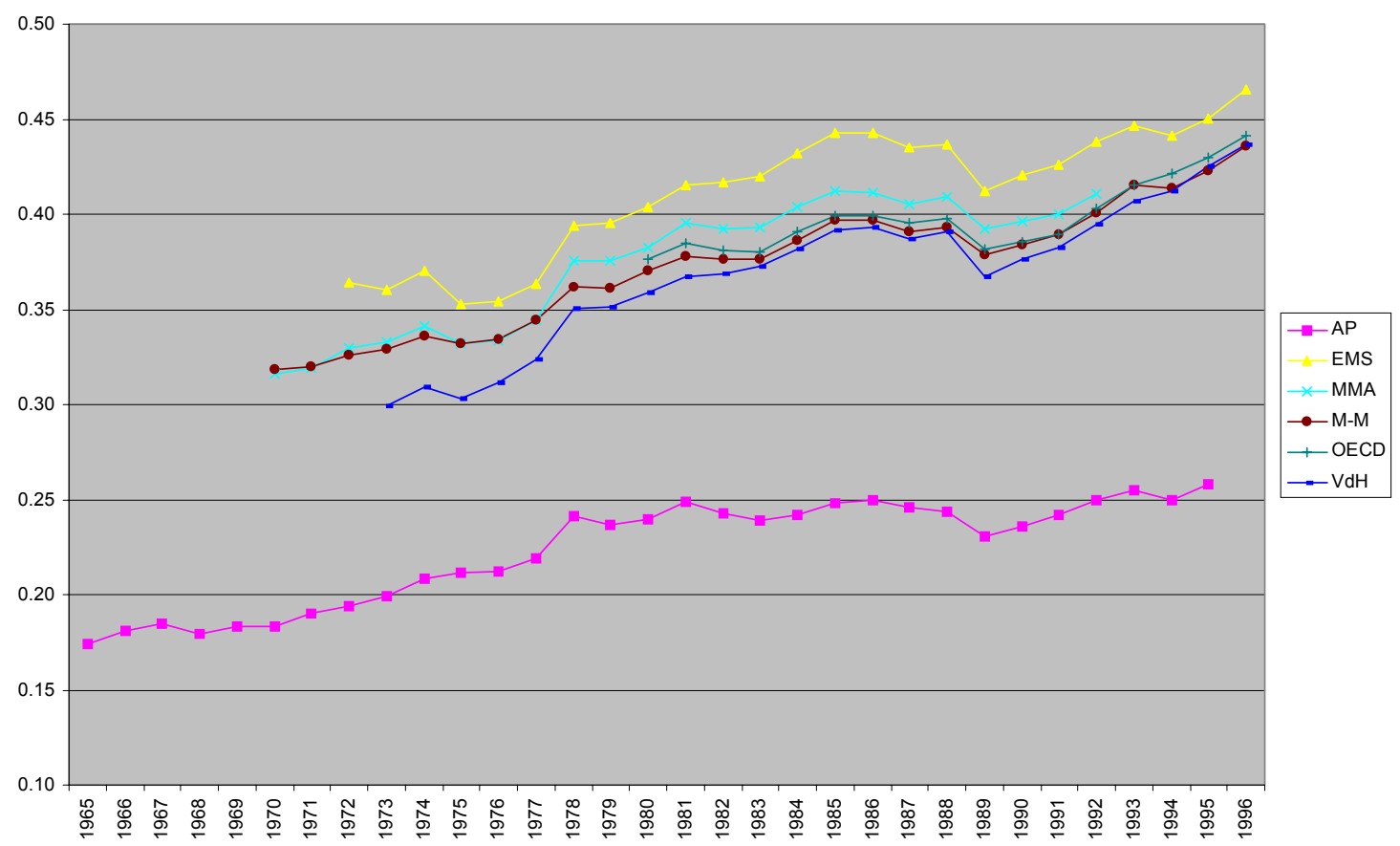

Figure 2. Various indicators for the tax burden on labour for Belgium.

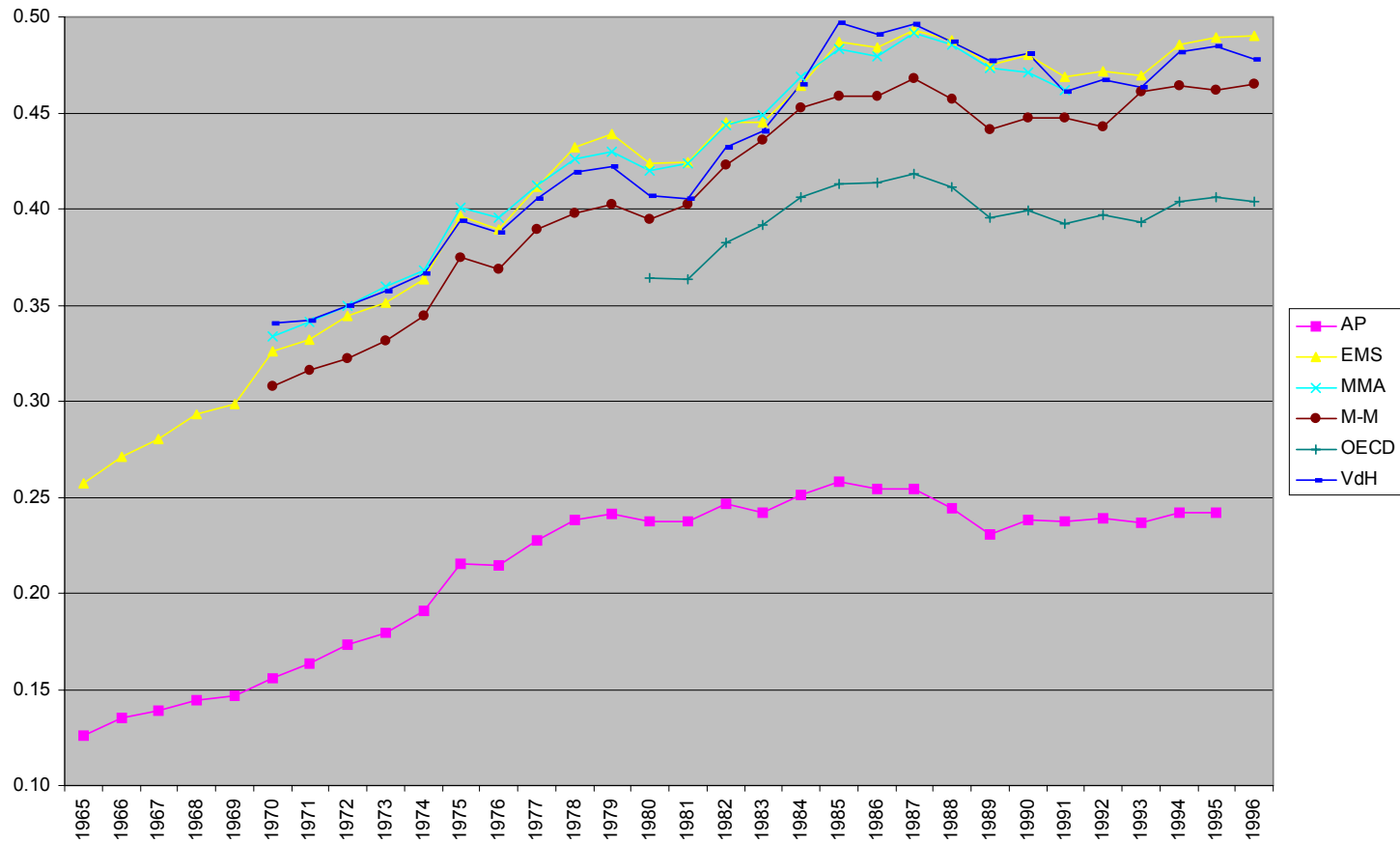




\section{Empirical Results}

This section presents, for illustrative purposes only, the results of some well-known models in which some indicator for the tax burden on labour has been used to examine to which extent the choice of a certain proxy drives the outcomes. We start with unemployment using the model and data of Daveri and Tabellini (2000). ${ }^{18}$ So we take their model specification, sample of countries included and time period covered. The model estimated is:

$\mathrm{U}_{\mathrm{i}, \mathrm{t}}=$ constant $_{\mathrm{i}}+\beta \mathrm{TAX}_{\mathrm{i}, \mathrm{t}}+\gamma_{1} \mathrm{UB}_{\mathrm{i}, \mathrm{t}}+\gamma_{2} \mathrm{EP}_{\mathrm{i}, \mathrm{t}}+\mathrm{e}_{\mathrm{it}}$,

where UB is unemployment benefit and EP is employment protection. ${ }^{19}$ These authors argue that labour taxes will have the strongest effect on unemployment if wage negotiations are decentralised and trade unions are powerful but not too large. Therefore, they partition their sample in three groups: continental Europe (Austria, Belgium, France, Germany, Greece, Ireland, Italy, Luxembourg, Netherlands, Portugal, Spain, UK (1965-80) and Australia and New Zealand), the Anglo-Saxon countries (Canada, Switzerland, UK (1981-96), USA and Japan) and the Nordic countries (Denmark, Finland, Iceland, Norway and Sweden). They report that no correlation between unemployment and labour taxes can be detected across countries. However, when they differentiate between the three groups of countries in their panel over the period 1965-95 they find a very significant effect of labour taxes in continental Europe.

The first column of table 4 reports our replication of model of Daveri and Tabellini (2000) as reported in the first column of their table 9. The model includes country specific constants, which is in line with the outcome of the likelihood ratio test $\left(\chi^{2}=131.02\right.$ with $\left.p=0.00\right)$. Our results are exactly the same as those of Daveri and Tabellini (2000). The coefficient of the labour tax ratio in continental-Europe is significantly different from the coefficient of the labour tax ratio in the Nordic and Anglo-Saxon countries. The same conclusion is reached if the model is estimated with additional time-fixed effects (not shown).

If tax ratios like those of Mendoza et al. (1997) are used, like the data of Martinez-Mongay (2000) and Volkerink and De Haan (2001) very similar results are found (see column 4 and 6 of table 4, respectively). ${ }^{20}$ This does not hold for the OECD labour tax ratio (column 5). This is probably due the limited time period for which the OECD indicator is available (1981-95/96). It is quite interesting that if alternative proxies for the tax burden on labour are used, again very similar results are found. ${ }^{21}$ This holds for the indicators of Alesina-Perotti (column 2) and Elmeskov et al. (column 3). So it seems that the general conclusion is not very sensitive with respect to the choice of the indicator for the tax burden on labour; this is in line with the reported high correlation between most indicators.

As pointed out before, one objection to the use of tax ratios on labour in a model for unemployment is that these tax ratios do not take indirect taxes into account. Columns (7) and (8) of table 4 therefore present the outcomes if we adjust the labour tax ratios of Mendoza et al. (1997) and Martinez-Mongay (2000) to include taxes on consumption. The basic conclusion does not change: in the continental European countries taxes exert a negative influence on unemployment. 
Table 4. Some simple panel regressions using the Daveri-Tabellini model, 14 OECD countries, 5-year averages, 1965-95 (dependent variable: unemployment rate, $U)^{a}$

\begin{tabular}{|c|c|c|c|}
\hline & (1) & (2) & (3) \\
\hline Tax proxy: & MMA (DT) & $\mathrm{AP}$ & EMS \\
\hline$\tau_{\text {labEUR }}$ & $0.54(8.60)$ & $0.75(7.62)$ & $0.30(5.59)$ \\
\hline$\tau_{\text {labANGLO }}$ & $0.25(2.36)$ & $0.44(2.05)$ & $0.22(1.78)$ \\
\hline$\tau_{\text {labNORDIC }}$ & $0.11(0.71)$ & $0.23(1.60)$ & $-0.10(-0.62)$ \\
\hline UB & $0.14(2.82)$ & $0.21(5.45)$ & $0.30(4.61)$ \\
\hline EP & $-1.00(-1.76)$ & $-1.45(-2.39)$ & $-0.76(-1.24)$ \\
\hline $\mathrm{R}^{2}$ (adj.) & 0.78 & 0.73 & 0.70 \\
\hline $\begin{array}{l}\text { F-test that } \tau \text { 's are } \\
\text { equal }\end{array}$ & $6.96(0.2 \%)$ & $5.32(0.7 \%)$ & $3.79(2.8 \%)$ \\
\hline No. Obs. & 84 & 84 & $82^{b}$ \\
\hline & (4) & (5) & (6) \\
\hline Tax proxy: & M-M & OECD & VDH \\
\hline$\tau_{\text {labEUR }}$ & $0.58(5.49)$ & $0.02(0.06)$ & $0.55(4.26)$ \\
\hline$\tau_{\text {labANGLO }}$ & $0.19(0.81)$ & $0.00(0.01)$ & $0.82(1.03)$ \\
\hline$\tau_{\text {labNORDIC }}$ & $0.19(0.93)$ & $0.54(1.64)$ & $-0.10(-0.14)$ \\
\hline UB & $0.29(3.00)$ & $0.13(0.98)$ & $-0.04(-0.28)$ \\
\hline EP & $-3.02(-3.08)$ & $-4.07(-1.67)$ & $5.46(1.80)$ \\
\hline $\mathrm{R}^{2}$ (adj.) & 0.79 & 0.80 & 0.69 \\
\hline $\begin{array}{l}\text { F-test that } \tau \text { 's are } \\
\text { equal }\end{array}$ & $2.94(6.5 \%)$ & $1.20(32.0 \%)$ & $0.58(57.7 \%)$ \\
\hline No. Obs. & $55^{\mathrm{c}}$ & $42^{\mathrm{d}}$ & 24 \\
\hline & (7) & (8) & \\
\hline Tax proxy: & MMAadj (DT) & M-Madj & \\
\hline$\tau_{\text {labEUR }}$ & $0.28(5.92)$ & $0.61(4.71)$ & \\
\hline$\tau_{\text {labANGLO }}$ & $0.23(1.83)$ & $0.20(0.75)$ & \\
\hline
\end{tabular}




\begin{tabular}{|l|l|l|l|}
\hline$\tau_{\text {labNORDIC }}$ & $-0.10(-0.72)$ & $0.14(0.55)$ & \\
\hline UB & $0.28(4.00)$ & $0.27(2.39)$ & \\
\hline EP & $-0.30(-0.50)$ & $-2.45(-2.37)$ & \\
\hline $\mathrm{R}^{2}$ (adj.) & 0.71 & 0.78 & \\
\hline F-test that $\tau$ 's are & $4.10(2.1 \%)$ & $3.13(5.5 \%)$ & \\
equal & & & \\
\hline No. Obs. & 81 & 55 & \\
\hline
\end{tabular}

Notes:

${ }^{a}$ Countries included are Australia, Belgium, Canada, Finland, France, Germany, Italy, Japan, the Netherlands, Norway, Spain, Sweden, United Kingdom, and the United States. The periods considered are 1965/66-1970, 1971-1975, 1976-1980, 1981-1985, 1986-1990, and 1991-1995/96. Estimation is with country dummies (no time dummies). T-statistics in parentheses.

${ }^{\mathrm{b}} 82$ observations due to missing observations for Norway for the periods 1965/66-1970 and 19711975.

${ }^{c}$ No observations available for Australia, Canada, Norway, and the period 1965/66-1970.

${ }^{\mathrm{d}}$ Only data available for 1980 onwards.

We have also estimated the unemployment model of Nickell (1997), which is very similar to the model of Nickell and Layard (1999). This model is:

$\mathrm{U}_{\mathrm{i}, \mathrm{t}}=$ constant $+\beta \mathrm{TAX}_{\mathrm{i}, \mathrm{t}}+\gamma_{1} \mathrm{EP}_{\mathrm{i}, \mathrm{t}}+\gamma_{2} \mathrm{RR}_{\mathrm{i}, \mathrm{t}}+\gamma_{3} \mathrm{BD}_{\mathrm{i}, \mathrm{t}}+\gamma_{4} \mathrm{ALMP}_{\mathrm{i}, \mathrm{t}}+\gamma_{5} \mathrm{UD}_{\mathrm{i}, \mathrm{t}}+\gamma_{6} \mathrm{UCI}_{\mathrm{i}, \mathrm{t}}+\gamma_{7} \mathrm{CO}_{\mathrm{i}, \mathrm{t}}+$ $\gamma_{8} \mathrm{CPI}_{\mathrm{i}, \mathrm{t}}+\gamma_{9}$ Dummy $_{8994}+\mathrm{e}_{\mathrm{it}}$,

where RR is the replacement rate, BD benefit duration, ALMP active labour market policies, UD labour union density, UCI union coverage index, $\mathrm{CO}$ co-ordination, CPI change in inflation. Again we have used the same set of countries (20 OECD countries) and time periods (1983-88 and 198994 ) as in the original studies. ${ }^{22}$ It follows that Nickell's total tax ratio is significant (column 1 of table 5). The same result shows up for AP, EMS, MMA, M-M and OECD (columns 2-6), albeit that the MMA indicator is only significant at the 10 per cent level. This outcome is quite remarkable, as - in contrast to the Nickell ratio - these proxies only take a limited number of taxes into account. Only the coefficient the VDH indicator is not significantly different from zero. However, if we adjust the labour tax ratios by including taxes paid on consumption, the coefficient of the tax ratio of Volkerink-De Haan also becomes significantly different from zero (not shown). 
Table 5. Some simple panel regressions using the Nickell model, 20 OECD countries, 1983-88 and 1989-94, (dependent variable: $\log$ unemployment rate, $U)^{\mathrm{a}}$

\begin{tabular}{|c|c|c|c|c|}
\hline & (1) & (2) & (3) & (4) \\
\hline Tax proxy: & $\mathrm{NL}$ & AP & EMS & MMA \\
\hline TAX & $0.03(4.88)$ & $0.05(3.26)$ & $0.03(3.58)$ & $0.02(1.85)$ \\
\hline EP & $0.01(0.74)$ & $0.02(1.58)$ & $0.03(1.68)$ & $0.02(0.87)$ \\
\hline RR & $0.01(2.63)$ & $0.01(2.63)$ & $0.01(2.64)$ & $0.01(1.36)$ \\
\hline $\mathrm{BD}$ & $0.11(2.59)$ & $0.05(1.29)$ & $0.08(1.81)$ & $0.09(1.70)$ \\
\hline ALMP & $-0.03(-4.51)$ & $-0.02(-3.26)$ & $-0.02(-3.62)$ & $-0.02(-2.81)$ \\
\hline UD & $0.01(3.36)$ & $0.01(1.38)$ & $0.01(2.04)$ & $0.01(2.40)$ \\
\hline UCI & $0.30(1.85)$ & $0.29(2.01)$ & $0.28(1.51)$ & $0.35(1.68)$ \\
\hline $\mathrm{CO}$ & $-0.45(-7.34)$ & $-0.42(-7.76)$ & $-0.45(-6.52)$ & $-0.43(-4.88)$ \\
\hline CPI & $0.04(2.06)$ & $0.03(1.33)$ & 0.05 (1.77) & $0.05(1.39)$ \\
\hline Dummy $_{8994}$ & $0.33(3.16)$ & $0.22(2.32)$ & $0.29(2.57)$ & $0.33(2.40)$ \\
\hline $\mathrm{R}^{2}$ (adj.) & 0.72 & 0.69 & 0.67 & 0.54 \\
\hline No. obs. & 40 & $37^{b}$ & 39 & $35^{\mathrm{c}}$ \\
\hline & (5) & (6) & (7) & \\
\hline Tax proxy: & M-M & OECD & VDH & \\
\hline TAX & $0.04(4.46)$ & $0.03(2.48)$ & $0.00(0.24)$ & \\
\hline EP & $0.00(0.08)$ & $0.03(1.66)$ & $0.00(0.08)$ & \\
\hline RR & $0.01(2.93)$ & $0.01(1.83)$ & $0.01(0.73)$ & \\
\hline $\mathrm{BD}$ & $0.05(1.08)$ & $0.09(1.80)$ & $-0.04(-0.38)$ & \\
\hline ALMP & $-0.02(-3.40)$ & $-0.02(-3.20)$ & $0.05(2.14)$ & \\
\hline UD & $0.00(1.05)$ & $0.01(2.57)$ & $0.00(-1.01)$ & \\
\hline UCI & $0.19(1.10)$ & $0.22(1.06)$ & $0.32(1.06)$ & \\
\hline $\mathrm{CO}$ & $-0.47(-7.21)$ & $-0.44(-5.89)$ & $-0.38(-4.99)$ & \\
\hline CPI & $0.05(2.33)$ & $0.05(1.69)$ & $0.00(0.02)$ & \\
\hline Dummy $_{8994}$ & $0.13(1.38)$ & $0.31(2.52)$ & $-0.01(-0.03)$ & \\
\hline $\mathrm{R}^{2}$ (adj.) & 0.73 & 0.61 & 0.51 & \\
\hline
\end{tabular}




\begin{tabular}{|l|l|l|l|l|}
\hline No. obs. & $30^{\mathrm{d}}$ & 39 & $17^{\mathrm{e}}$ & \\
\hline
\end{tabular}

Notes:

${ }^{a}$ Countries included are Australia, Austria, Belgium, Canada, Denmark, Finland, France, Germany, Ireland, Italy, Japan, the Netherlands, New Zealand, Norway, Portugal, Spain, Sweden, Switzerland, United Kingdom, and the United States. The periods considered are 1983-1988 and 1989-1994. Estimation is with time random effects.

${ }^{\mathrm{b}}$ No observations available for Switzerland.

${ }^{\mathrm{c}}$ No observations available for Ireland and Portugal.

${ }^{\mathrm{d}}$ No observations available for Australia, Canada, New Zealand, Norway, Switzerland.

e No observations available for Australia, Canada, Denmark, New Zealand, Norway, Portugal, Spain, Sweden, Switzerland, and the United States.

Next, we examine whether tax ratios are related to private investment, following Mendoza et al. (1997). Mendoza et al. use an endogenous growth model to derive the theoretically expected signs of the tax coefficients. In this model, investment and growth are jointly determined by taxes and other exogenous variables. Output is produced with a Cobb-Douglas, CRS technology that uses human capital $\mathrm{H}$ and physical capital $\mathrm{K}$ as inputs:

$$
Y_{t}=A\left(v_{t} K_{t}\right)^{\alpha}\left(u_{t} H_{t}\right)^{1-\alpha}
$$

where $v(u)$ is the share of $\mathrm{K}(\mathrm{H})$ devoted to the production of goods. Mendoza et al. (1997) conclude that taxes can affect growth and investment in various ways that may offset each other. This is the case for the tax on capital, as a higher tax rate reduces the after-tax rate of return on physical capital, thereby reducing growth. At the same time, a tax on capital reduces $(\mathrm{vK} / \mathrm{uH})$, thus increasing the gross-of-tax return on capital, which positively affects growth. In contrast, a tax on human capital raises $(\mathrm{vK} / \mathrm{uH})$, reduces the gross-of-tax return on capital, which has a negative impact on growth. A tax on consumption will affect the labour-leisure decision, which in turn affects the capital/labour ratio in production. In the model, the effect of a consumption tax on growth is negative. Simulations of the model, using calibrated parameters, suggest that the effect of reducing taxes on capital and labour and increasing consumption taxes hardly effects investment, thereby supporting Harberger's claim that the tax mix is not an important determinant of long-run growth and investment rates. In line with these simulations, the empirical results of Mendoza et al. (1997) suggest that the effect of capital and labour taxes on investment is strongly negative, whereas the effect of consumption tax is strongly positive. They also find that tax rates are generally not statistically significant for explaining growth.

We start with replicating the private investment model of Mendoza et al. (1997) using a time fixed effects model for five-year averages of investment (I). The only explanatory variables considered are the convergence factor (log of GDP per capita in 1965, $\mathrm{Y}_{0}$ ) and the tax ratios on labour, capital and consumption ( $\tau_{\text {lab }}, \tau_{\text {cap }}$ and $\tau_{\text {con }}$, respectively). The estimated panel model is:

$\mathrm{I}_{\mathrm{i}, \mathrm{t}}=\alpha \mathrm{Y}_{0 \mathrm{i}}+\beta_{1} \tau_{\text {lab i,t }}+\beta_{2} \tau_{\text {cap i,t }}+\beta_{3} \tau_{\text {con i,t }}+$ time $_{\mathrm{t}}$

where $t$ denotes a five-year period index and $i$ is the country index (data are the same as in Volkerink et al., 2002). Following Mendoza et al. (1997), time dummies (time ${ }_{t}$ ) are also included although the likelihood ratio test indicates that it is not necessary to include them $\left(\chi^{2}=4.32\right.$ with pvalue $=0.36$ ), while country dummies are not included. 
The results as shown in column (1) of table 6 are very similar to those of Mendoza et al. (1997): the consumption tax ratio has a significant positive coefficient, while the impact of the other tax ratios is significantly negative. ${ }^{23}$ The same results show up for the M-M indicator (column 2), whereas the results with the OECD tax ratios differ, which is probably due to the limited period for which these data are available (column 3).

Table 6. Some simple panel regressions for private investment (dependent variable: gross investment as share of GDP)

\begin{tabular}{|c|c|c|c|}
\hline & $(1)$ & (2) & (3) \\
\hline Estimation by: & $\begin{array}{l}\text { Time fixed } \\
\text { Effects }\end{array}$ & $\begin{array}{l}\text { Time fixed } \\
\text { Effects }\end{array}$ & $\begin{array}{l}\text { Time fixed } \\
\text { Effects }\end{array}$ \\
\hline Explanatory var: & $\mathrm{MMA}^{\mathrm{a}}$ & $\mathrm{M}-\mathrm{M}^{\mathrm{b}}$ & $\mathrm{OECD}^{\mathrm{c}}$ \\
\hline $\mathrm{Y}_{0}$ & $1.70(1.17)$ & $-0.43(-0.37)$ & $0.15(0.10)$ \\
\hline$\tau_{\mathrm{lab}}$ & $-0.16(-4.04)$ & $-0.24(-3.51)$ & $-0.09(-1.29)$ \\
\hline$\tau_{\text {cap }}$ & $-0.28(-4.16)$ & $-0.15(-1.90)$ & $0.04(1.46)$ \\
\hline$\tau_{\text {con }}$ & $0.17(2.61)$ & $0.19(2.04)$ & $0.02(0.28)$ \\
\hline $\mathrm{R}^{2}$ (adj.) & 0.33 & 0.37 & 0.12 \\
\hline No. Obs. & 60 & 80 & 54 \\
\hline & (4) & (5) & (6) \\
\hline Explanatory var: & $\mathrm{MMA}^{\mathrm{a}}$ & $\mathrm{M}-\mathrm{M}^{\mathrm{b}}$ & $\mathrm{OECD}^{\mathrm{c}}$ \\
\hline Estimation by: & $\begin{array}{l}\text { Time random } \\
\text { Effects, country } \\
\text { Dummies }\end{array}$ & $\begin{array}{l}\text { Time random } \\
\text { Effects, country } \\
\text { Dummies }\end{array}$ & $\begin{array}{l}\text { Time random } \\
\text { Effects, country } \\
\text { Dummies }\end{array}$ \\
\hline $\mathrm{Y}_{0}$ & $2.66(17.04)$ & $2.85(19.08)$ & $2.70(10.84)$ \\
\hline$\tau_{\text {lab }}$ & $-0.19(-2.80)$ & $-0.51(-11.83)$ & $-0.57(-5.35)$ \\
\hline$\tau_{\text {cap }}$ & $-0.05(-0.98)$ & $-0.05(-0.63)$ & $0.02(0.86)$ \\
\hline$\tau_{\text {con }}$ & $-0.03(-0.28)$ & $0.22(1.82)$ & $0.67(3.96)$ \\
\hline $\mathrm{R}^{2}$ (adj.) & 0.84 & 0.84 & 0.71 \\
\hline No. Obs. & 60 & 80 & 54 \\
\hline & (7) & (8) & (9) \\
\hline
\end{tabular}




\begin{tabular}{|l|l|l|l|}
\hline Explanatory var: & $\mathrm{MMA}^{\mathrm{a}}$ & $\mathrm{M}^{\mathrm{b}}$ & $\mathrm{OECD}^{\mathrm{c}}$ \\
\hline Estimation by: & Time random & Time random & Time random \\
& $\begin{array}{l}\text { Effects, country } \\
\text { Eummies }\end{array}$ & $\begin{array}{l}\text { Effects, country } \\
\text { Dummies }\end{array}$ & Dummies \\
\hline $\mathrm{Y}_{0}$ & $2.99(15.44)$ & $2.79(7.17)$ & $2.11(3.90)$ \\
\hline$\tau_{\text {labEUR }}$ & $-0.37(-4.13)$ & $-0.49(-79)$ & $-0.51(-3.32)$ \\
\hline$\tau_{\text {labANGLO }}$ & $-0.19(-2.70)$ & $-0.47(-2.89)$ & $-0.32(-1.32)$ \\
\hline$\tau_{\text {labNORDIC }}$ & $0.25(2.18)$ & $-0.56(-7.38)$ & $-0.77(-4.67)$ \\
\hline$\tau_{\text {cap }}$ & $-0.08(-1.73)$ & $-0.06(-0.77)$ & $0.02(0.81)$ \\
\hline$\tau_{\text {con }}$ & $-0.36(-2.78)$ & $0.24(1.97)$ & $0.66(3.87)$ \\
\hline $\mathrm{R}^{2}$ (adj.) & 0.87 & 0.83 & 0.70 \\
\hline$\chi^{2}(2)$-test that & $21.69(0.0 \%)$ & $0.61(73.8 \%)$ & $3.03(22.0 \%)$ \\
$\tau_{\text {lab's are equal }}$ & & & 54 \\
\hline No. Obs. & 60 & 80 & \\
\hline
\end{tabular}

Notes:

${ }^{a}$ Countries included are Australia, Austria, Belgium, Canada, Denmark, Finland, France, Italy, Japan, the Netherlands, New Zealand, Norway, Spain, Sweden, Switzerland, United Kingdom, the United States. The periods considered are 1965/66-1970, 1971-1975, 1976-1980, 1981-1985, and 1986-1990.

${ }^{\mathrm{b}}$ Countries included are Austria, Belgium, Denmark, Finland, France, Greece, Ireland, Italy, Japan, Luxembourg, the Netherlands, Portugal, Spain, Sweden, United Kingdom, the United States. The periods considered are 1971-1975, 1976-1980, 1981-1985, 1986-1990, and 1991-1995/96.

${ }^{\mathrm{c}}$ Countries included are Australia, Austria, Belgium, Canada, Denmark, Finland, France, Greece, Ireland, Italy, Japan, the Netherlands, New Zealand, Norway, Portugal, Spain, Sweden, Switzerland, United Kingdom, and the United States. The periods considered are 1981-1985, 19861990, and 1991-1995/96.

So far, we have followed Mendoza et al. (1997) and only used time dummies. However, as shown by Islam (1995), neglecting unobserved differences between countries induces an omitted variables problem. The hypothesis that country dummies can be ignored is strongly rejected. The next three columns of table 6 therefore show the results if we employ a model with country dummies. It follows that the results change drastically: the capital tax ratio is no longer significant, no matter which indicator is used. The labour tax ratio becomes always significant. These results differ substantially from those reported by Mendoza et al. (1997). However, we like to stress that this is not so much caused by the choice of the tax ratios but by the specification of the model.

Finally, we have explicitly tested the argument of Daveri and Tabellini (2000) that high labour taxes in combination with the institutional set-up of the labour market have affected investment. According to these authors, an exogenous and lasting increase in labour costs reduces labour demand. Due to a substitution of capital for labour, the marginal product of capital falls, diminishing the incentive to invest. Daveri and Tabellini presume that this effect will be strongest if wage negotiations are decentralised and trade unions are powerful but not too large. So, the labour 
tax ratio is negatively related to investment, depending on the institutional characteristics of the labour market. In other words, the labour tax ratio should be different among the three groups of countries as distinguished by Daveri and Tabellini (2000). Rows (7)-(9) in table 6 present the outcomes. The results are mixed. Only if we use the Mendoza tax ratio as provided by Daveri and Tabellini, we can reject the hypothesis that the coefficients of all labour tax ratios are the same. These results therefore do not yield much support for the Daveri-Tabellini point of view concerning the impact of labour taxes on investment.

\section{Concluding Comments}

In this paper we have first surveyed the way in which the tax burden on labour has been proxied for in recent multi-country macro-economic studies. Most of these studies estimate unemployment models, in which the tax burden on labour is one of the explanatory variables. Basically two (not mutually exclusive) approaches can be discerned. In one group of studies indicators for the taxwedge are used, in another group of studies tax ratios are used as proxies for the tax burden on labour. We find that even though the various proxies for the tax burden on labour differ substantially, their correlation is generally quite high.

The most important difference between various proxies for the tax wedge used is whether or not consumption taxes are included in the calculation of the tax wedge. By definition, consumption taxes are not included in the calculation of labour tax ratios. One may therefore wonder whether labour tax ratios are the proper variables to be used in estimating macro-economic, multi-country models for unemployment. The fundamental methodological problem in constructing labour income tax ratios is that most tax categories as distinguished in the OECD Revenue Statistics relate to more than one macroeconomic category (labour and capital income). Consequently, it is impossible to calculate tax ratios without using some technique to artificially separate out the amounts to be allocated to various macroeconomic categories. We argue that the way this is done by Mendoza et al. (1994) and in more recent studies is rather unreliable.

Finally, we have examined to what extent the conclusions of some studies change if some alternative indicator for the tax burden on labour is employed. We conclude that the significance of the impact of the tax burden on unemployment is not very sensitive with respect to the choice of the indicator. This is in line with the reported high correlation between the various indicators. Essentially the same conclusion holds for our replications of the Nickell-model: in almost all variants the coefficient of the tax variable is significant. Another finding is that - in contrast to the reasoning of Daveri and Tabellini (2000) - the significance of the labour tax ratio in the simple investment model of Mendoza et al. (1997) does not depend on the institutional characteristics of the labour market. 


\section{References}

Adema, W. (1999), "Net Public Social Expenditure", OECD Labour Market and Social Policy Occasional Papers, Nr. 39.

Adema, W., M. Einerhand, B. Eklind, J. Lotz, and M. Pearson (1996), "Net Public Social Expenditure", OECD Labour Market and Social Policy Occasional Papers, Nr. 19.

Alesina, A. and R. Perotti (1997), "The Welfare State and Competitiveness", American Economic Review, 87 (5), 921-939.

Bean, C.R, R. Layard, and S. Nickell (1986), "The Rise in Unemployment: A Multi-Country

Study", Economica, 53, 1-22.

Belot., M., and J.C. van Ours (2001), "Unemployment and Labor Market Institutions; An Empirical Analysis", OSA working paper, Nr. 2001-10.

Blanchard, O. and J. Wolfers (2000), "The role of shocks and institutions in the rise of European unemployment: The aggregate evidence", The Economic Journal, 110, C1-C33.

Carey, D. and J. Rabesona (2002), "Average Effective Tax Rates on Capital, Labour and Consumption", Paper presented at CESifo Venice Summer Institute, 2002.

Daveri, F. (2001), "Labor taxes and unemployment: A survey of the aggregate evidence", Mimeo. Daveri, F. and G. Tabellini (2000), "Unemployment, growth and taxation in industrial countries", Economic Policy, 30, 49-104.

Directorate General II of the European Commission (1997), "Effective Taxation and Tax Convergence in the EU and the OECD", unpublished memo 5/1997.

Directorate General XXI of the European Commission (1998), "How to measure the burden of taxation: Implicit tax rates according to the (primary) functional incidence approach", Mimeo.

Elmeskov, J., J.P. Martin and S. Scarpetta (1998), "Key lessons for Labour Market Reforms: Evidence from OECD Countries' Experiences”, Swedish Economic Policy Review, 5(2), 205-252. Eurostat (1997), Structures of the Taxation Systems in the European Union, 1970-1995. Series 2A, Luxembourg.

Fiorito, R. and F. Padrini (2001), "Distortionary taxation and labour market performance", Oxford Bulletin of Economics and Statistics, 63(2), 173-196.

Hamermesh, D.S. (1993), Labour Demand, Princeton University Press, Princeton N.J..

Heady, C. (2002), “The 'Taxing Wages' Approach to Measuring the Tax Burden on Labour”, Paper presented at CESifo Venice Summer Institute, 2002.

Islam, N. (1995), "Growth Empirics: A Panel Data Approach" , Quarterly Journal of Economics, 110, 1127-1170.

Knoester, A. and P. van der Windt (1987), "Real wages and taxation in 10 OECD Countries", Oxford Bulletin of Economics and Statistics, 49, 151-169.

Koskela, E. (2001), "Labour taxation and employment in trade union models: A partial survey", Bank of Finland Discussion papers, Nr. 12001.

Layard, R., S. Nickell, and R. Jackman (1991), Unemployment: Macroeconomic Performance and the Labor Market, Oxford University Press, New York, NY.

Lucas, R.E. (1990), "Supply-side economics: An analytical review", Oxford Economic Papers, 42, 293-316.

Martinez-Mongay, C. (2000), “ECFIN's Effective Tax Rates: Properties and Comparisons with other Tax Indicators", European Commission Economic Papers, Nr. 146.

McKee, M.J., J.J.C. Visser and P.G. Saunders (1986), "Marginal Tax Rates on the Use of Labour and Capital in OECD Countries", OECD Economic Studies, 7, 45-101.

Mendoza, E.G., G.M. Milesi-Ferretti and P. Asea (1997), "On the ineffectiveness of tax policy in altering long-run growth: Harberger's superneutrality conjecture”, Journal of Public Economics, 66(1), 99-126.

Mendoza, E.G., A. Razin and L.L. Tesar (1994), "Effective tax rates in macroeconomics. Crosscountry estimates of tax rates on factor incomes and consumption", Journal of Monetary

Economics, 34(3), 297-323. 
Nickell, S.J. (1997), "Unemployment and labour market rigidities: Europe versus North America," Journal of Economic Perspectives, 11, 55-74.

Nickell, S.J. and R. Layard (1999), "Labor Market Institutions and Economic Performance", in: O. Ashelfelter and D. Card (eds), Handbook of Labor Economics, vol. 3C, North Holland, Amsterdam. Nickell, S.J., L. Nunziata, W. Ochel and G. Quintini (2001), "The Beveridge Curve, Unemployment and Wages in the OECD from the 1960s to the 1990s", Centre for Economic Performance Discussion Paper, Nr. 502.

Nunziata, L. (2001), "Institutions and Wage Determination: A Multi-Country Approach”, Nuffield College, mimeo.

OECD (1995), Taxation, Employment and Unemployment, Paris: OECD.

OECD (2000), "Effective Average Tax Rates On Capital, Labour, and Consumption Goods: Crosscountry Estimates", Economics Department, Working Paper, Nr. 258.

Palley, T.I. (2001), "The Role of Institutions and Policies in Creating High European

Unemployment: The Evidence", mimeo.

Scarpetta, S. (1996), "Assessing the role of labour market policies and institutional settings on unemployment: A cross-country study", OECD Economic Studies, 26, 43-98.

Volkerink, B. and J. de Haan (2001), "Tax Ratios: A Critical Survey," OECD Tax Policy Studies, No. 5.

Volkerink, B., J-E. Sturm and J. de Haan (2002), “Tax ratios in macro-economics: Do taxes really matter?", Empirica, 29, 209-224. 
Appendix. Data sources.

Sources for table 3:

\begin{tabular}{|l|l|l|l|l|l|l|}
\hline AP & EMS & NL & MMA & M-M & OECD & VDH \\
\hline $\begin{array}{l}\text { Own } \\
\text { calculations } \\
\begin{array}{l}\text { using OECD } \\
\text { data }\end{array}\end{array}$ & $\begin{array}{l}\text { Own } \\
\text { calculations } \\
\text { using OECD } \\
\text { data }\end{array}$ & Palley (2001) & $\begin{array}{l}\text { Data } \\
\text { published by } \\
\text { authors } \\
\text { (MMA) }\end{array}$ & $\begin{array}{l}\text { Data } \\
\text { published by } \\
\text { authors }\end{array}$ & $\begin{array}{l}\text { Data } \\
\text { published by } \\
\text { authors }\end{array}$ & $\begin{array}{l}\text { Data } \\
\text { published by } \\
\text { authors }\end{array}$ \\
\hline
\end{tabular}

Sources for table 4:

\begin{tabular}{|l|l|l|l|l|l|}
\hline AP & EMS & MMA & M-M & OECD & VDH \\
\hline $\begin{array}{l}\text { Own } \\
\text { calculations } \\
\text { using OECD } \\
\text { data }\end{array}$ & $\begin{array}{l}\text { Own } \\
\text { calculations } \\
\text { using OECD } \\
\text { data }\end{array}$ & $\begin{array}{l}\text { Data } \\
\text { published by } \\
\text { authors (DT) }\end{array}$ & $\begin{array}{l}\text { Data } \\
\text { published by } \\
\text { authors }\end{array}$ & $\begin{array}{l}\text { Data } \\
\text { published by } \\
\text { authors }\end{array}$ & $\begin{array}{l}\text { Data } \\
\text { published by } \\
\text { authors }\end{array}$ \\
\hline
\end{tabular}

Sources for table 5:

All data for the Nickell model taken from Palley (2001). The other indicators for the tax burden on labour are as in table 3 .

\section{Notes}

${ }^{1}$ Still, the OECD (1995, p. 93) stresses that while tax rates are important for the labour supply and demand decisions of households and firms, there "is no evident simple link between the tax burden and the level of unemployment, which suggests that taxation may not be the principal determinant of unemployment". However, this conclusion may reflect that labour market characteristics are not properly taken into account. Indeed, Daveri and Tabellini (2000) report that no correlation between unemployment and labour taxes can be detected across countries. However, when they differentiate between the three groups of countries depending on differences in labour market institutions, they find a very significant effect of labour taxes in continental Europe.

${ }^{2}$ Similarly, Alesina and Perotti (1997) report that the degree of shifting of labour taxation is a hump-shaped function of the degree of centralisation of labour markets, peaking in countries with an intermediate degree of centralisation.

${ }^{3}$ Some may doubt whether analyses at the macro-level make sense at all, as a single rate averaged across tax payers may be problematic since it neglects e.g. the distribution of labour income. Still, as will be explained in more detail in section 2, a substantial literature has recently addressed the impact of labour taxes on unemployment from a multi-country, macro-economic perspective.

${ }^{4}$ Country specific studies come to a variety of conclusions. For a summary, see OECD (1995).

${ }^{5}$ Earlier studies provide evidence on the impact of taxes in reduced-form wage equations (see e.g. Knoester and van der Windt, 1987). Hamermesh (1993, table 5.1) summarises studies estimating Phillip-curve-type equations with a (payroll) tax term appended. According to Daveri (2001), there was no consensus in this earlier literature either about the size of the tax shift or about the likely causes of the estimated differences.

${ }^{6}$ Mendoza et al. (1994, p. 302) write that their method "by suggesting the use of data on pre- and post-tax income and prices, produces aggregate effective tax rates that in fact correspond to realized average tax rates. These tax rates aggregate the information on statutory taxes, credits, deductions, and exemptions implicit in national accounts and revenue statistics in a manner that captures the overall tax burden from each tax and maintains consistency with the representative agent framework." Section 3 discusses the approach of Mendoza et al. (1994) in more detail. 
${ }^{7}$ There are alternative approaches to model unemployment and its relationship to taxes, like efficiency wage models, search and matching models and bargaining models. See e.g. Koskela (2001) for further details.

${ }^{8}$ We owe this point to Steven Clark.

${ }^{9}$ We owe this point to the Peter Birch Sørensen.

${ }^{10}$ Bean et al. (1986) give some more details about the calculation of this total tax ratio. It consists of the sum of 1. Ratio of employers' contributions to social security and pensions to the wage bill; 2 . Household contributions to social security and direct taxes as proportion of income; and 3. Indirect taxes (net of subsidies) as a proportion of consumers' expenditure.

${ }^{11}$ The APW income level is the average of earning of production workers in the manufacturing sector. Thus, despite its name, the APW does not represent the income level of an average production worker nor is it otherwise a meaningful average for workers or households (McKee et al., 1986).

${ }^{12}$ Apart from the use of different indicators for the tax burden on labour, the studies of Elmeskov et al. (1998) and Blanchard and Wolfers also differ somewhat in terms of country and period coverage and with respect to the other variables taken up in the model. The main difference between both studies, however, is that in contrast with Blanchard and Wolfers, Elmeskov et al. interact their tax variable with proxies for the level of centralization of the labour market.

${ }^{13}$ A serious concern with the study of Daveri and Tabellini is the way labour market institutions are taken into account by simply dividing the countries in three groups. On the basis of which criteria this is done remains rather unclear from the paper. According to Nunziata (2001), the composition of each country group suffers from a certain degree of subjectivity. To what extent the grouping of a certain country affects the results is not examined. There are various aspects of the labour market that may influence unemployment and labour costs and not necessarily in the same direction. In his model for labour costs, Nunziata (2001) divides his countries also in three groups depending on either the degree of bargaining co-ordination or the degree of bargaining centralisation. In the first case, the tax variable has a positive impact on all groups of countries and not only on the intermediate group. In the second case, the impact of the tax variable is not significant in centralised countries only, while in decentralised and intermediate countries wage costs are significantly affected by employment taxation.

${ }^{14}$ Tax ratios are average tax rates rather than marginal tax rates, which - in general - might seem more relevant to evaluate the impact of taxation. However, Fiorito and Padrini (2001) argue that this point should not be overstated for two reasons. First, average and marginal tax rates are considerably correlated as shown by Nickell and Layard (1999). Second, marginal tax rates are plagued by larger measurement errors than tax ratios. We doubt, however, whether this second argument is correct (see below). Finally, for some issues (including the effect of taxes on unemployment) average tax rates should be used.

${ }^{15}$ The personal income tax ratio is sometimes used as an intermediary step in calculating the labour income tax ratio, and should therefore be considered as well.

${ }^{16}$ Martinez-Mongay (2000) uses the so-called AMECO (Annual Macroeconomic) database. This database is less detailed than the Revenue Statistics and the detailed tables from the National Accounts statistics from the OECD. It is also not available to the public. The main advantage compared to the use of OECD data is that these are available more rapidly, and are available for a longer time period.

${ }^{17}$ In calculating these correlations we have used - as far as possible - the data as published in the original studies. Only for AP and EMS data of the OECD have been used, given the general 
definitions of the various tax burdens provided by the authors. See the Appendix for our data sources.

${ }^{18}$ We thank the authors for kindly providing their data.

${ }^{19}$ One may criticise this specification as many potential control variables are not included. However, as our aim is to examine how sensitive the results are for the choice of a certain indicator for the tax burden on labour, we have used the same model as Daveri and Tabellini (2000).

${ }^{20}$ However, the F-test that the coefficients of the various tax indicators are the same cannot be rejected (at the 5\% significance level) for the M-M and $\mathrm{VdH}$ indicators.

${ }^{21}$ The Nickell indicator is not used here due to data availability.

${ }^{22}$ The data have been taken from Palley (2001).

${ }^{23}$ See column 1 of table 4 of Mendoza et al. (1997). 


\title{
CESifo Working Paper Series
}

\author{
(for full list see www.cesifo.de)
}

899 Ronald MacDonald and Cezary Wójcik, Catching Up: The Role of Demand, Supply and Regulated Price Effects on the Real Exchange Rates of Four Accession Countries, March 2003

900 R. Selten, M. Schreckenberg, T. Pitz, T. Chmura, and S. Kube, Experiments and Simulations on Day-to-Day Route Choice-Behaviour, April 2003

901 Stergios Skaperdas, Restraining the Genuine Homo Economicus: Why the Economy Cannot be Divorced from its Governance, April 2003

902 Yin-Wong Cheung, Menzie D. Chinn, and Antonio Garcia Pascual, What Do We Know about Recent Exchange Rate Models? In-Sample Fit and Out-of-Sample Performance Evaluated, April 2003

903 Mika Widgrén, Enlargements and the Principles of Designing EU - Decision-Making Procedures, April 2003

904 Phornchanok Cumperayot, Dusting off the Perception of Risk and Returns in FOREX Markets, April 2003

905 Kai A Konrad, Inverse Campaigning, April 2003

906 Lars P. Feld and Stefan Voigt, Economic Growth and Judicial Independence: Cross Country Evidence Using a New Set of Indicators, April 2003

907 Giuseppe Bertola and Pietro Garibaldi, The Structure and History of Italian Unemployment, April 2003

908 Robert A.J. Dur and Otto H. Swank, Producing and Manipulating Information, April 2003

909 Christian Gollier, Collective Risk-Taking Decisions with Heterogeneous Beliefs, April 2003

910 Alexander F Wagner, Mathias Dufour, and Friedrich Schneider, Satisfaction not Guaranteed - Institutions and Satisfaction with Democracy in Western Europe, April 2003

911 Ngo Van Long, Raymond Riezman, and Antoine Soubeyran, Trade, Wage Gaps, and Specific Human Capital Accumulation, April 2003

912 Andrea Goldstein, Privatization in Italy 1993-2002: Goals, Institutions, Outcomes, and Outstanding Issues, April 2003 
913 Rajshri Jayaraman and Mandar Oak, The Signaling Role of Municipal Currencies in Local Development, April 2003

914 Volker Grossmann, Managerial Job Assignment and Imperfect Competition in Asymmetric Equilibrium, April 2003

915 Christian Gollier and Richard Zeckhauser, Collective Investment Decision Making with Heterogeneous Time Preferences, April 2003

916 Thomas Moutos and William Scarth, Some Macroeconomic Consequences of Basic Income and Employment Subsidies, April 2003

917 Jan C. van Ours, Has the Dutch Miracle Come to an End?, April 2003

918 Bertil Holmlund, The Rise and Fall of Swedish Unemployment, April 2003

919 Bernd Huber and Marco Runkel, Optimal Design of Intergovernmental Grants under Asymmetric Information, April 2003

920 Klaus Wälde, Endogenous Business Cycles and Growth, April 2003

921 Ramon Castillo and Stergios Skaperdas, All in the Family or Public? Law and Appropriative Costs as Determinants of Ownership Structure, April 2003

922 Peter Fredriksson and Bertil Holmlund, Improving Incentives in Unemployment Insurance: A Review of Recent Research, April 2003

923 Bernard M.S. van Praag and Adam S. Booij, Risk Aversion and the Subjective Time Discount Rate: A Joint Approach, April 2003

924 Yin-Wong Cheung, Kon S. Lai, and Michael Bergman, Dissecting the PPP Puzzle: The Unconventional Roles of Nominal Exchange Rate and Price Adjustment, April 2003

925 Ugo Trivellato and Anna Giraldo, Assessing the 'Choosiness' of Job Seekers. An Exploratory Approach and Evidence for Italy, April 2003

926 Rudi Dornbusch and Stanley Fischer, International Financial Crises, April 2003

927 David-Jan Jansen and Jakob de Haan, Statements of ECB Officials and their Effect on the Level and Volatility of the Euro-Dollar Exchange Rate, April 2003

928 Mario Jametti and Thomas von Ungern-Sternberg, Assessing the Efficiency of an Insurance Provider - A Measurement Error Approach, April 2003

929 Paolo M. Panteghini and Guttorm Schjelderup, Competing for Foreign Direct Investments: A Real Options Approach, April 2003

930 Ansgar Belke, Rainer Fehn, and Neil Foster, Does Venture Capital Investment Spur Employment Growth?, April 2003 
931 Assar Lindbeck, Sten Nyberg, and Jörgen W. Weibull, Social Norms and Welfare State Dynamics, April 2003

932 Myrna Wooders and Ben Zissimos, Hotelling Tax Competition, April 2003

933 Torben M. Andersen, From Excess to Shortage - Recent Developments in the Danish Labour Market, April 2003

934 Paolo M. Panteghini and Carlo Scarpa, Irreversible Investments and Regulatory Risk, April 2003

935 Henrik Jacobsen Kleven and Claus Thustrup Kreiner, The Marginal Cost of Public Funds in OECD Countries. Hours of Work Versus Labor Force Participation, April 2003

936 Klaus Adam, George W. Evans, and Seppo Honkapohja, Are Stationary Hyperinflation Paths Learnable?, April 2003

937 Ulrich Hange, Education Policy and Mobility: Some Basic Results, May 2003

938 Sören Blomquist and Vidar Christiansen, Is there a Case for Public Provision of Private Goods if Preferences are Heterogeneous? An Example with Day Care, May 2003

939 Hendrik Jürges, Kerstin Schneider, and Felix Büchel, The Effect of Central Exit Examinations on Student Achievement: Quasi-experimental Evidence from TIMSS Germany, May 2003

940 Samuel Bentolila and Juan F. Jimeno, Spanish Unemployment: The End of the Wild Ride?, May 2003

941 Thorsten Bayindir-Upmann and Anke Gerber, The Kalai-Smorodinsky Solution in Labor-Market Negotiations, May 2003

942 Ronnie Schöb, Workfare and Trade Unions: Labor Market Repercussions of Welfare Reform, May 2003

943 Marko Köthenbürger, Tax Competition in a Fiscal Union with Decentralized Leadership, May 2003

944 Albert Banal-Estañol, Inés Macho-Stadler, and Jo Seldeslachts, Mergers, Investment Decisions and Internal Organisation, May 2003

945 Kaniska Dam and David Pérez-Castrillo, The Principal-Agent Matching Market, May 2003

946 Ronnie Schöb, The Double Dividend Hypothesis of Environmental Taxes: A Survey, May 2003

947 Erkki Koskela and Mikko Puhakka, Stabilizing Competitive Cycles with Distortionary Taxation, May 2003 
948 Steffen Huck and Kai A. Konrad, Strategic Trade Policy and Merger Profitability, May 2003

949 Frederick van der Ploeg, Beyond the Dogma of the Fixed Book Price Agreement, May 2003

950 Thomas Eichner and Rüdiger Pethig, A Microfoundation of Predator-Prey Dynamics, May 2003

951 Burkhard Heer and Bernd Süssmuth, Cold Progression and its Effects on Income Distribution, May 2003

$952 \mathrm{Yu}-\mathrm{Fu}$ Chen and Michael Funke, Labour Demand in Germany: An Assessment of NonWage Labour Costs, May 2003

953 Hans Gersbach and Hans Haller, Competitive Markets, Collective Decisions and Group Formation, May 2003

954 Armin Falk, Urs Fischbacher, and Simon Gächter, Living in Two Neighborhoods Social Interactions in the LAB, May 2003

955 Margarita Katsimi, Training, Job Security and Incentive Wages, May 2003

956 Clemens Fuest, Bernd Huber, and Jack Mintz, Capital Mobility and Tax Competition: A Survey, May 2003

957 Edward Castronova, The Price of 'Man' and 'Woman': A Hedonic Pricing Model of Avatar Attributes in a Synthetic World, June 2003

958 Laura Bottazzi and Marco Da Rin, Financing Entrepreneurial Firms in Europe: Facts, Issues, and Research Agenda, June 2003

959 Bruno S. Frey and Matthias Benz, Being Independent is a Great Thing: Subjective Evaluations of Self-Employment and Hierarchy, June 2003

960 Aaron Tornell and Frank Westermann, Credit Market Imperfections in Middle Income Countries, June 2003

961 Hans-Werner Sinn and Wolfgang Ochel, Social Union, Convergence and Migration, June 2003

962 Michael P. Devereux, Measuring Taxes on Income from Capital, June 2003

963 Jakob de Haan, Jan-Egbert Sturm and Bjørn Volkerink, How to Measure the Tax Burden on Labour at the Macro-Level?, June 2003 